\title{
Agro-industry production of sugarcane grown using subsurface drip fertigation with nitrogen and potassium
}

\author{
Fábio Nunes do Nascimento(1), Aderson Soares de Andrade Júnior ${ }^{(2)}$, Edson Alves Bastos ${ }^{(2)}$, \\ Valdenir Queiroz Ribeiro(2) and Alzeneide da Silva Lopes ${ }^{(3)}$
}

\begin{abstract}
(1)Instituto Federal de Educação, Ciência e Tecnologia do Piauí, Campus Valença, Avenida Joaquim Manoel, s/no, CEP 64300-000 Valença do Piauí, PI, Brazil. E-mail: fabio.nunes@ifpi.edu.br ${ }^{(2)}$ Embrapa Meio-Norte, Avenida Duque de Caxias, oㅜ 5.650, Buenos Aires, CEP 64006-220 Teresina, PI, Brazil. E-mail: aderson.andrade@embrapa.br, edson.bastos@embrapa.br, valdenir.queiroz@embrapa.br (3)Universidade Federal do Vale do São Francisco, Avenida José de Sá Maniçoba, s/non, Campus Universitário de Juazeiro, CEP 56304-917 Juazeiro, BA, Brazil. E-mail: agro.neide@hotmail.com
\end{abstract}

\begin{abstract}
The objective of this work was to evaluate the stalk yield, technological quality parameters, and sugar and alcohol productions in the first sugarcane (Saccharum officinarum) crop cycle, according to the response to $\mathrm{N}$ and $\mathrm{K}_{2} \mathrm{O}$ applications by subsurface drip fertigation. The experiment was carried out in a dystrophic Ultisol, in a randomized complete block design with four replicates. The treatments consisted of a $2^{\mathrm{X}}+2 \mathrm{X}+1$ incomplete factorial arrangement with the application of $60,80,120,160$, and $180 \mathrm{~kg} \mathrm{ha}^{-1} \mathrm{~N}$ and $60,80,120,160$, and $180 \mathrm{~kg} \mathrm{ha}^{-1} \mathrm{~K}_{2} \mathrm{O}$. The maximum estimated yield $\left(217.5 \mathrm{Mg} \mathrm{ha}^{-1}\right)$ was obtained with the application of $180 \mathrm{~kg} \mathrm{ha}^{-1} \mathrm{~N}$ and $60 \mathrm{~kg} \mathrm{ha}^{-1} \mathrm{~K}_{2} \mathrm{O}$. Sugar and alcohol productions increased with $\mathrm{N}$ application above $120 \mathrm{~kg} \mathrm{ha}^{-1}$. The technological quality characteristics of soluble solids content, apparent sucrose in the juice/broth, apparent sucrose in sugarcane, purity, and fiber show the highest averages with the application of $180 \mathrm{~kg} \mathrm{ha}^{-1} \mathrm{~N}$ and $60 \mathrm{~kg} \mathrm{ha}^{-1} \mathrm{~K}_{2} \mathrm{O}$.

Index terms: Saccharum officinarum, alcohol production, fertilizer, irrigation management, sugarcane juice.

\section{Rendimento agroindustrial da cana-de-açúcar fertirrigada por gotejamento subsuperficial com nitrogênio e potássio}

\begin{abstract}
Resumo - O objetivo deste trabalho foi avaliar a produtividade de colmos, os parâmetros tecnológicos de qualidade e o rendimento de açúcar e álcool no primeiro ciclo de cana-planta (Saccharum officinarum), em resposta à aplicação de $\mathrm{N} \mathrm{e} \mathrm{K}_{2} \mathrm{O}$ em fertirrigação por gotejamento subsuperficial. O experimento foi realizado em um Argissolo Vermelho-Amarelo distrófico, em um delineamento experimental de blocos ao acaso, com quatro repetições. Os tratamentos consistiram de um arranjo fatorial incompleto $2^{\mathrm{x}}+2 \mathrm{X}+1$ com a aplicação de 60, 80, 120, 160 e $180 \mathrm{~kg} \mathrm{ha}^{-1}$ de $\mathrm{N}$ e de 60, 80, 120, 160, $180 \mathrm{~kg} \mathrm{ha}^{-1} \mathrm{de}_{2} \mathrm{O}$. A máxima produtividade de colmos estimada (217,5 $\left.\mathrm{Mg} \mathrm{ha}^{-1}\right)$ foi obtida com a aplicação de $180 \mathrm{~kg} \mathrm{ha}^{-1} \mathrm{~N} \mathrm{e} 60 \mathrm{~kg} \mathrm{ha}^{-1} \mathrm{~K}_{2} \mathrm{O}$. Os rendimentos de açúcar e álcool aumentaram com a aplicação de adubação nitrogenada acima de $120 \mathrm{~kg} \mathrm{ha}^{-1}$. As características tecnológicas de qualidade dos sólidos solúveis totais, sacarose aparente no caldo, sacarose aparente na cana, pureza e fibra apresentam médias mais elevadas com a aplicação de $180 \mathrm{~kg} \mathrm{ha}^{-1}$ de $\mathrm{N}$ e $60 \mathrm{~kg} \mathrm{ha}^{-1}$ de $\mathrm{K}_{2} \mathrm{O}$.
\end{abstract}

Termos para indexação: Saccharum officinarum, produção de álcool, fertilizante, manejo da irrigação, caldo de cana.

\section{Introduction}

Among the products obtained from sugarcane, alcohol and sugar are the most used by the population. The harvested sugarcane area in Brazil was estimated in 8,654.2 thousand hectares in the 2015/2016 crop year (Acompanhamento..., 2016). The sugar production decreased about $5.8 \%$ - from 35.6 million to 33.5 million tons in $2015 / 2016$. As to ethanol, there was an increase from 28.7 to 30.5 billion liters, that is, 1.8 billion liters, or $6.3 \%$, during the $2015 / 2016$ harvest (Acompanhamento..., 2016). Stalk, sugar and alcohol productivity of the irrigated plant depend on the amount of applied water, irrigation management combined with the amount of fertilizer, plant cultivar, cut age, soil type, and climate (Silva et al., 2014).

In Brazil, sugarcane is predominantly cultivated under dry conditions. However, irrigation is often present in technicized agriculture, resulting in higher yields, better product quality, and rainfall independence (Dalri et al., 2008). Without using irrigation and fertilization, crop production can be significantly affected by the amount of biomass produced, especially taking into consideration the technological quality of
Pesq. agropec. bras., Brasília, v.53, n.12, p.1346-1354, Dec. 2018 DOI: 10.1590/S0100-204X2018001200007 Creative Commons Attribution 4.0 International License 
the product. These two practices, together with the climatic conditions of the growing site, are of great importance for the plant development of plant yield (Correia et al., 2014).

In the Northeast, areas irrigated with conventional sprinkler, commonly used as salvage irrigation, have stalk gain averaged in only $5.4 \mathrm{Mg} \mathrm{ha}^{-1}$. However, subsurface drip irrigation, even if still incipient, has provided stalk yields of up to $190 \mathrm{Mg} \mathrm{ha}^{-1}$ (Souza et al., 2012), with gains of up to $112.6 \mathrm{Mg} \mathrm{ha}^{-1}$, in comparison to the conventional system, considering the 2010/2011 harvest, with a mean of $77.4 \mathrm{Mg} \mathrm{ha}^{-1}$. Drip irrigation associated with the practice of fertigation provides better plant development, higher stalk yield, and a better final quality product (Andrade Júnior et al., 2012).

Several studies evaluated the effect of irrigation and fertilization on the biomass production and on the technological quality of sugarcane juice (Dalri et al., 2008; Carvalho et al., 2009; Teixeira Filho et al., 2013). Regarding the superficial drip irrigation, it is important to mention the studies of Carvalho et al. (2008), Dalri et al. (2008), Silva et al. (2009), Farias et al. (2009) and Teixeira et al. (2016), who studied the technological quality of the irrigated and fertilized sugarcane. However, these studies were carried out in climate and soil conditions that are different from those of the Northeast of Brazil. With fertigation, the possibility of applying fertilizer, mainly $\mathrm{N}$ and $\mathrm{K}$, becomes an alternative that can bring benefits to crop planning (Dalri et al., 2008), besides being an increasingly relevant practice to supply water conditions and nutritional requirements of sugarcane, especially when the crop is grown under subsurface drip irrigation (Andrade Júnior et al., 2012).

The objective of this work was to evaluate the stalk yield, technological quality parameters, and sugar and alcohol productions in the first sugarcane crop cycle, according to the response to $\mathrm{N}$ and $\mathrm{K}_{2} \mathrm{O}$ applications by subsurface drip fertigation.

\section{Materials and Methods}

The experiment was carried out in the experimental field of Embrapa Meio-Norte, Teresina, PI, Brazil $\left(5^{\circ} 05^{\prime} \mathrm{S}\right.$ and $42^{\circ} 29^{\prime} \mathrm{W}$, at $72 \mathrm{~m}$ altitude), from June 2014 to June 2015. The climate of the region is C1sA'a', according to Thornthwaite \& Mather (1955) - subhumid, megatermic, with moderate water surplus in the summer, and $32.2 \%$ concentration of potential evapotranspiration in September, October, and November (Bastos \& Andrade Júnior, 2014).

The area was previously occupied by Jatropha curcas L. for seven years, which can be associated with the higher-potassium content of the soil at $0.0-0.2 \mathrm{~m}$ soil depth, due to the crop fertilization. The soil was classified as Argissolo Vermelho-Amarelo distrófico (Melo et al., 2014), i.e., Ultisol, whose chemical and physical-hydraulic characterization is presented (Table 1).

The sugarcane (Saccharum officinarum L.) cultivar RB92579 was used in the first crop cycle/year, and it is characterized by high agricultural productivity, high tillering during the first and second years of the crop, good row closure, high height, frequent lodging, medium to late maturation, extended useful period of industrialization (UPI), high ATR and fast recovery to water stress (Daros et al., 2010).

Double rows spaced at $1.5 \times 0.5 \times 2.0 \mathrm{~m}$ were used with a cultivation cycle of 366 days. Fertigation treatments were applied from August 04, 2014, to February 6, 2015. Then, crop irrigation was carried out until February 16, 2015, when it was suspended due to the rainy season in the region. The soil was prepared with a plowing, then later harrowed, and planting grooves were opened. Soil liming was performed two months before planting, and it consisted of $2.0 \mathrm{Mg} \mathrm{ha}^{-1}$ of dolomite limestone, calculated according to the soil chemical analysis. Planting was manually carried out in June 6, 2014. Stalks/stems were selected in segments with three gems, distributed in the grooves with 0.3 $m$ deep, in order to obtain an average of 15 gems per linear meter.

The experiment was conducted in a randomized complete block design with four replicates. For the present study, the incomplete factorial arrangement $2^{\mathrm{X}}+2 \mathrm{X}+1$ was used (Pimentel Gomes, 2009). The treatments consisted of applications of $60,80,120,160$, $180 \mathrm{~kg} \mathrm{ha}^{-1} \mathrm{~N}$ and 60, 80, 120, 160, $180 \mathrm{~kg} \mathrm{ha}^{-1} \mathrm{~K}_{2} \mathrm{O}$.

The fertigation with $\mathrm{N}$ and $\mathrm{K}$ was defined as a percentage of the respective recommended doses according to the soil analysis. At the planting, 30\% of the recommended dose of $\mathrm{K}_{2} \mathrm{O}$ and $\mathrm{P}_{2} \mathrm{O}_{5}$ were applied, whose sources were, respectively, potassium chloride and triple superphosphate. The remaining $70 \%$ were applied via fertigation, for which $\mathrm{K}_{2} \mathrm{O}$ was weekly applied as potassium chloride, and $\mathrm{P}_{2} \mathrm{O}_{5}$ was monthly

Pesq. agropec. bras., Brasília, v.53, n.12, p.1346-1354, Dec. 2018 DOI: 10.1590/S0100-204X2018001200007 
applied as monoammonium phosphate (MAP). Nitrogen was applied $100 \%$ via fertigation. The plots were composed of three double rows of plants, with 10 $\mathrm{m}$ length by $6 \mathrm{~m}$ wide, totaling $60 \mathrm{~m}^{2}$, with an useful area of $40 \mathrm{~m}^{2}$ formed by the central double rows.

The $\mathrm{N}$ and $\mathrm{K}$ doses were applied via fertigation using a hydraulic positive displacement injector (TMB hydraulic pump). The control of opening and closing of the plots in the field, for application of the irrigation depth and doses of $\mathrm{N}$ and $\mathrm{K}$, was performed by hydraulic records installed on trestles at the entrances of each plot. The applied water depths were measured by a hydrometer located in the control head.

Fertigation started on August 4, 2014, at 60 days after planting, and extended until mid-January 2015.

Table 1. Chemical and physicohydraulic characterization of the soil of the experimental area.

\begin{tabular}{|c|c|c|c|}
\hline \multirow{2}{*}{ Variable $^{(1)}$} & \multicolumn{3}{|c|}{ Depth (m) } \\
\hline & $0.0-0.2$ & $0.2-0.4$ & $0.4-0.6$ \\
\hline & \multicolumn{3}{|c|}{ Chemical parameter } \\
\hline $\mathrm{OM}\left(\mathrm{g} \mathrm{kg}^{-1}\right)$ & 13.88 & 7.64 & 6.46 \\
\hline pH $\mathrm{H}_{2} \mathrm{O}$ & 5.76 & 5.22 & 5.28 \\
\hline $\mathrm{P}\left(\mathrm{mg} \mathrm{dm}^{-3}\right)$ & 16.21 & 13.56 & 12.77 \\
\hline $\mathrm{H}+\mathrm{Al}\left(\mathrm{cmol}_{\mathrm{c}} \mathrm{dm}^{-3}\right)$ & 3.30 & 3.85 & 4.73 \\
\hline $\mathrm{Al}\left(\mathrm{cmol}_{\mathrm{c}} \mathrm{dm}^{-3}\right)$ & 0.07 & 0.95 & 1.27 \\
\hline $\mathrm{Ca}\left(\mathrm{cmol}_{\mathrm{c}} \mathrm{dm}^{-3}\right)$ & 1.21 & 0.38 & 0.42 \\
\hline $\operatorname{Mg}\left(\mathrm{cmol}_{\mathrm{c}} \mathrm{dm}^{-3}\right)$ & 0.69 & 0.11 & 0.10 \\
\hline $\mathrm{K}\left(\mathrm{cmol}_{\mathrm{c}} \mathrm{dm}^{-3}\right)$ & 0.23 & 0.07 & 0.12 \\
\hline $\mathrm{Na}\left(\mathrm{cmol}_{\mathrm{c}} \mathrm{dm}^{-3}\right)$ & 0.02 & 0.02 & 0.04 \\
\hline $\mathrm{CEC}\left(\mathrm{cmol}_{\mathrm{c}} \mathrm{dm}^{-3}\right)$ & 5.43 & 4.40 & 5.37 \\
\hline$V(\%)$ & 39.59 & 13.18 & 12.63 \\
\hline \multirow[t]{2}{*}{$\mathrm{m}(\%)$} & 3.15 & 62.09 & 65.12 \\
\hline & \multicolumn{3}{|c|}{ Physicohydraulic parameter } \\
\hline Bulk density $\left(\mathrm{Mg} \mathrm{m}^{-3}\right)$ & 1.434 & 1.603 & 1.577 \\
\hline Sand $\left(\mathrm{g} \mathrm{kg}^{-1}\right)$ & 609.7 & 626.0 & 573.3 \\
\hline Silt $\left(\mathrm{g} \mathrm{kg}^{-1}\right)$ & 278.8 & 225.3 & 245.7 \\
\hline Clay $\left(\mathrm{g} \mathrm{kg}^{-1}\right)$ & 111.5 & 148.8 & 181.0 \\
\hline $\operatorname{\theta fc}\left(\mathrm{m}^{3} \mathrm{~m}^{-3}\right)$ & 0.245 & 0.245 & 0.268 \\
\hline Өpwp $\left(\mathrm{m}^{3} \mathrm{~m}^{-3}\right)$ & 0.055 & 0.081 & 0.125 \\
\hline $\mathrm{AWC}(\mathrm{mm})$ & 37.97 & 32.85 & 28.59 \\
\hline EAW(mm) & 18.98 & 16.43 & 14.30 \\
\hline Texture & $\begin{array}{l}\text { Sandy } \\
\text { loam }\end{array}$ & Sandy loam & Sandy loam \\
\hline
\end{tabular}

(1) OM, organic matter; ${ }^{(2)} \mathrm{CEC}$, cation exchange capacity; V, base saturation; $\mathrm{m}$, aluminium saturation; Өfc, field capacity; Opwp: permanent wilting point; AWC, available water capacity; EAW, easily available water.
Nitrogen was applied from August to December, 2014 $-15 \%$ in Aug.; $20 \%$ in Sept.; $25 \%$ in Oct.; $20 \%$ in Nov.; $15 \%$ in Dec. - , and in January, 2015, at 5\%. Potassium was applied at $30 \%$ at planting; the remaining $70 \%$ were applied via fertigation, from August to December, $2014-10 \%$ in Aug.; 15\% in Sept.; 20\% in Oct.; 25\% in Nov.; 20\% in Dec. -, and in January , 2015, at 10\% (Andrade Júnior et al., 2012). Fertigations with N and $\mathrm{K}$ were performed once a week, always in the morning shift, and each operation lasted about one hour. During the six months of fertigation, 24 applications were performed.

The first fertilization followed the recommendation of Andrade Júnior et al. (2012). Micronutrients were applied by fertigation for all treatments in six months: $4.5 \mathrm{~kg} \mathrm{ha}^{-1}$ boric acid; $7.0 \mathrm{~kg} \mathrm{ha}^{-1}$ zinc oxide; $6.0 \mathrm{~kg} \mathrm{ha}^{-1}$ copper oxide; $11.0 \mathrm{~kg} \mathrm{ha}^{-1}$ manganese oxide, and $1.0 \mathrm{~kg}$ ha ${ }^{-1}$ sodium molybdate.

The irrigation layer was uniform and applied with basis on the crop evapotranspiration (ETc), which was obtained by reference evapotranspiration (ETo) estimated by the Penman-Monteith method, sugarcane cultivation coefficients $(\mathrm{Kc})$ were determined in the region, according to Andrade Júnior et al. (2017), at a daily time scale, using climatic data of an automatic meteorological station. The subsurface drip irrigation system was set $2 \mathrm{~m}$ between drip lines, buried at 0.25 $\mathrm{m}$ soil depth, in the center of the double rows of the plant.

The application of the water depths was carried out every Monday, Wednesday, and Friday, and the irrigation management was based on the hydrometer reading. On Mondays, the accumulated ETc of Friday, Saturday, and Sunday was applied. On Wednesday, the accumulated ETc of Monday and Tuesday was applied; and on Friday, the accumulated ETc of Wednesday and Thursday was applied.

At harvest, stalk yield $\left(\mathrm{Mg} \mathrm{ha} \mathrm{h}^{-1}\right)$, total sugar recovery $\left(\mathrm{Mg} \mathrm{ha}^{-1}\right)$ and alcohol production $\left(\mathrm{m}^{3} \mathrm{ha}^{-1}\right)$, and the technological parameters of sugarcane quality were evaluated. The stalk mass was measured in a dynamometer type electronic scale, and the determination of the technological variables was carried out for total soluble solids (Brix, \%), fiber content (\%), purity content, percentage of apparent sucrose in the juice/broth (POLjuice), and percentage of apparent sucrose in sugarcane (POLcane), according to the recommendations of Consecana-PE (2016). The 
estimation of the total sugar recovery and alcohol productivities followed the equations of Caldas (1998).

The regression on the variance analysis was used, in function of the t-test, and the best model was selected using the significances of each parameter. To a better analysis and results expression (avoiding discussion of complex interactions), a reduced model was adopted, containing the linear and quadratic isolate effects, and by the double interaction of the first degree, as $\mathrm{Y}=\mathrm{b}_{0}+\mathrm{b}_{1} \mathrm{~N}+\mathrm{b}_{2} \mathrm{~N}^{2}+\mathrm{b}_{3} \mathrm{~K}+\mathrm{b}_{4} \mathrm{~K}^{2}+\mathrm{b}_{5} \mathrm{NK}$, in which: $\mathrm{Y}$ is dependent variable; $b_{0}$ is the regression constant; $\mathrm{b}_{1}, \ldots, \mathrm{b}_{5}$, represent the coefficient of regression; and $\mathrm{N}$ and $\mathrm{K}$ are the independent variables, constituted by $\mathrm{N}$ and $\mathrm{K}_{2} \mathrm{O}$ doses, respectively.

The most adequate solution was also the function of the biological interpretation of the response function graphs. All statistical analyses were performed using the SAS software (SAS Institute Inc., Cary, NC, USA). The Table Curve 3D software (Jandel Scientific, San Rafael, CA, USA) was used to obtain the response surfaces of stalk yield, sugar and alcohol production, and juice/broth quality, as a function of the $\mathrm{N}$ and $\mathrm{K}_{2} \mathrm{O}$ applied doses.

\section{Results and Discussion}

During the experiment, water depths were applied as follows: $40.6 \mathrm{~mm}$ (August), $107.53 \mathrm{~mm}$ (September), $167.63 \mathrm{~mm}$ (October), $166.80 \mathrm{~mm}$ (November), 164.63 $\mathrm{mm}$ (December), $101.52 \mathrm{~mm}$ (January), and 36.46 $\mathrm{mm}$ (February). Total water depth applied during the experiment was $785.18 \mathrm{~mm}$. Irrigation and the rainfall totalized $1,804 \mathrm{~mm}$, which is within the range recommended (1,500-2,000 $\mathrm{mm})$ for sugarcane with 12 months cycle, according to Doorenbos \& Kassam (1979).

A total rainfall of $1,019 \mathrm{~mm}$ was observed between June, 2014, and June, 2015. The highest rainfall indexes were observed in February, March and April, 2015, totaling $792 \mathrm{~mm}$, which coincides with the rainy period of the region (Bastos \& Andrade Júnior, 2014).

The adjusted regressions to estimate the production variables (stalk yield, total sugar recovery, alcohol production) and the industrial quality variables [soluble solids (Brix), POLjuice, POLcane, purity and fiber (dependent variables)], according to the $\mathrm{N}$ and $\mathrm{K}_{2} \mathrm{O}$ doses combination (independent variables) are presented (Table 2). From the quadratic response of stalk yield to the applied $\mathrm{N}$ doses, it can be inferred that there was a stalk yield increase of sugarcane with $102 \mathrm{~kg} \mathrm{ha}^{-1} \mathrm{~N}$ and $104.7 \mathrm{~kg} \mathrm{ha}^{-1} \mathrm{~K}_{2} \mathrm{O}$ applications. This $\mathrm{N}$ value is higher than the $41 \mathrm{~kg} \mathrm{ha}^{-1}$ of $\mathrm{N}$ found for a quadratic function of stalk yield with the application of four different doses 0, 20, 40 and $60 \mathrm{~kg} \mathrm{ha}^{-1}$ (May et al., 2016).

$\mathrm{N}$ and $\mathrm{K}$ had a quadratic effect on the content of soluble solids, with $15.5 \%$ (Table 2). The same pattern was observed for POLjuice, POLcane, and purity, with a quadratic effect of $\mathrm{N}$ and $\mathrm{K}$, and the estimated values were $12.12,10.13$ and $78.04 \%$, respectively, with the following critical levels: $130.7 \mathrm{~kg} \mathrm{ha}^{-1} \mathrm{~N}$ and 112.86 $\mathrm{kg} \mathrm{ha}^{-1} \mathrm{~K}_{2} \mathrm{O}$, for soluble solids/Brix; $120.3 \mathrm{~kg} \mathrm{ha}^{-1} \mathrm{~N}$ and $119.42 \mathrm{~kg} \mathrm{ha}^{-1} \mathrm{~K}_{2} \mathrm{O}$, for POLjuice; and $120.9 \mathrm{~kg} \mathrm{ha}^{-1}$

Table 2. Regression equation for the juice quality parameters and fertigated sugarcane (Saccharum officinarum) yield ${ }^{(1)}$.

\begin{tabular}{|c|c|c|c|c|c|c|c|c|c|c|c|}
\hline Variable & Intercept & $\mathrm{N}$ & $\mathrm{N}^{2}$ & $\mathrm{~K}_{2} \mathrm{O}$ & $\mathrm{K}_{2} \mathrm{O}^{2}$ & $\mathrm{NK}_{2} \mathrm{O}$ & $\mathrm{R}^{2}$ & Type & $(\mathrm{N})$ & $\left(\mathrm{K}_{2} \mathrm{O}\right)$ & $\begin{array}{l}\text { Estimated } \\
\text { value }\end{array}$ \\
\hline Stalk yield $\left(\mathrm{Mg} \mathrm{ha}^{-1}\right)$ & 147.680 & $-0.3773^{\text {ns }}$ & $0.0052 * *$ & $0.7380 * *$ & - & $-0.0070 * * *$ & $0.85^{* * *}$ & Min & 102.1 & 104.7 & 165.59 \\
\hline Brix $(\%)$ & 29.334 & $-0.0784^{\circ}$ & $0.0003^{\circ}$ & $-0.1535^{* * *}$ & $0.0006^{* * *}$ & - & $0.63 * *$ & Min & 130.7 & 112.9 & 15.54 \\
\hline POL-juice (\%) & 28.614 & $-0.1083^{* *}$ & $0.0004 * *$ & $-0.1671 * * *$ & $0.0007 * * *$ & - & $0.35^{* *}$ & Min & 120.3 & 119.4 & 12.12 \\
\hline POL-cane (\%) & 24.659 & $-0.0918 * *$ & $0.0004 * *$ & $-0.1492 * * *$ & $0.0006^{* * *}$ & - & $0.39 * *$ & Min & 120.9 & 120.3 & 10.13 \\
\hline Purity (\%) & 107.560 & $-0.2873^{* *}$ & $0.0012 * * *$ & $-0.2024 *$ & $0.0008 *$ & - & $0.36^{*}$ & Min & 114.0 & 129.8 & 78.04 \\
\hline Fiber (\%) & 9.510 & $0.0521 * *$ & $-0.0002 * *$ & - & - & - & - & Max & - & 123.1 & 12.72 \\
\hline $\begin{array}{l}\text { Total sugar recovery } \\
\left(\mathrm{Mg} \mathrm{ha}^{-1}\right)\end{array}$ & 32.387 & $-0.1636^{*}$ & $0.0011 * * *$ & $-0.0811^{\mathrm{ns}}$ & $0.0007^{*}$ & $-0.0009^{*}$ & $0.52 * * *$ & Min & 122.6 & 132.6 & 16.97 \\
\hline $\operatorname{RBA}\left(\mathrm{M}^{3} \mathrm{ha}^{-1}\right)$ & 24.137 & $-0.1112 *$ & $0.0007 * *$ & $-0.0674^{\mathrm{ns}}$ & $0.0005 *$ & $-0.0005^{*}$ & $0.65^{* *}$ & Min & 123.6 & 123.8 & 13.07 \\
\hline
\end{tabular}


$\mathrm{N}$ and $120.3 \mathrm{~kg} \mathrm{ha}^{-1} \mathrm{~K}_{2} \mathrm{O}$, for POLcane, suggesting that the variables were affected in isolation by $\mathrm{N}$ and $\mathrm{K}$.

As to $\mathrm{N}$ and $\mathrm{K}$ interaction, no significant effect was observed. Carvalho et al. (2008), in an experiment with different water depths applied by a central pivot, with two levels of $\mathrm{N}$ and $\mathrm{K}_{2} \mathrm{O}$ fertilization $\left(\mathrm{N}_{0}=28 \mathrm{~kg} \mathrm{ha}^{-1} \mathrm{~N}\right.$ and $44 \mathrm{~kg} \mathrm{ha}^{-1} \mathrm{~K}_{2} \mathrm{O} ; \mathrm{N}_{1}=112 \mathrm{~kg} \mathrm{ha}^{-1} \mathrm{~N}$ and $164 \mathrm{~kg} \mathrm{ha}^{-1}$ $\mathrm{K}_{2} \mathrm{O}$ ), did not obtain a significant effect between the studied factors for soluble solids (Brix). Some authors studied the quality of the irrigated sugarcane using fertilization, and concluded that these factors did not influenced the juice/brock technological parameters of quality (Dalri et al., 2008; Silva et al., 2009; Teixeira et al., 2016).

As to the fiber variable, a quadratic behavior was observed for $\mathrm{N}$, with an estimated value of $12.7 \%$ and maximum of $123.1 \mathrm{~kg} \mathrm{ha}^{-1} \mathrm{~K}_{2} \mathrm{O}$. Rhein \& Silva (2017) reported that under well-irrigated soil conditions, without constraints of internodes length and stem whose cell walls have normal development, content of fibers is conditioned to the characteristics of the cultivar. There was interaction between $\mathrm{N}$ and $\mathrm{K}$ for both sugar yield and alcohol yield, with $122.6 \mathrm{~kg} \mathrm{ha}^{-1}$ $\mathrm{N}$ and $132.6 \mathrm{~kg} \mathrm{ha}^{-1} \mathrm{~K}_{2} \mathrm{O}$ applied for total sugar recovery yield, and $123.6 \mathrm{~kg} \mathrm{ha}^{-1} \mathrm{~N}$ and $123.6 \mathrm{~kg} \mathrm{ha}^{-1}$ $\mathrm{K}_{2} \mathrm{O}$ applied to alcohol yield. The estimated values were $16.9 \mathrm{Mg} \mathrm{ha}^{-1}$ for total sugar recovery yield, and $13.07 \mathrm{~m}^{3} \mathrm{ha}^{-1}$ for alcohol yield, indicating a productive potential with different variations among the levels applied.

Carvalho et al. (2009) worked with a combination of four irrigation depths and two levels of cover fertilization applied in the traditional way on an Argisol with the cultivar SP 791011 in cane plant. These authors obtained maximum yield for sugar of 15.29 $\mathrm{Mg} \mathrm{ha}^{-1}$ and alcohol $10.88 \mathrm{~m}^{3} \mathrm{ha}^{-1}$ smaller than those found in the present work. However, the values of $\mathrm{N}$ and $\mathrm{K}_{2} \mathrm{O}$ applied $276 \mathrm{~kg} \mathrm{ha}^{-1}\left(112 \mathrm{~N}\right.$ plus $164 \mathrm{~K}_{2} \mathrm{O}$ ) were higher than those applied via fertigation, which shows a better distribution by this system.

A significant interaction was observed between the $\mathrm{N}$ and $\mathrm{K}_{2} \mathrm{O}$ doses applied in the first cycle of the crop, which indicates the generation of response surfaces for the evaluation of the combined nitrogen and potassium effect for stalk yield (Table 2). The response surface generated for stalk yield presents a saddle point, which, according to Pimentel Gomes (2009), is a very common problem, since there are critical points that have both maximum and minimum characteristics (Figure 1).

When stalk yield was estimated, a minimum function with critical levels of $102.1 \mathrm{~kg} \mathrm{ha}^{-1} \mathrm{~N}$ and $104.7 \mathrm{~kg} \mathrm{ha}^{-1} \mathrm{~K}_{2} \mathrm{O}$, applied via subsurface fertigation, was obtained, as well as $165.59 \mathrm{Mg} \mathrm{ha}^{-1}$ for stalk yield
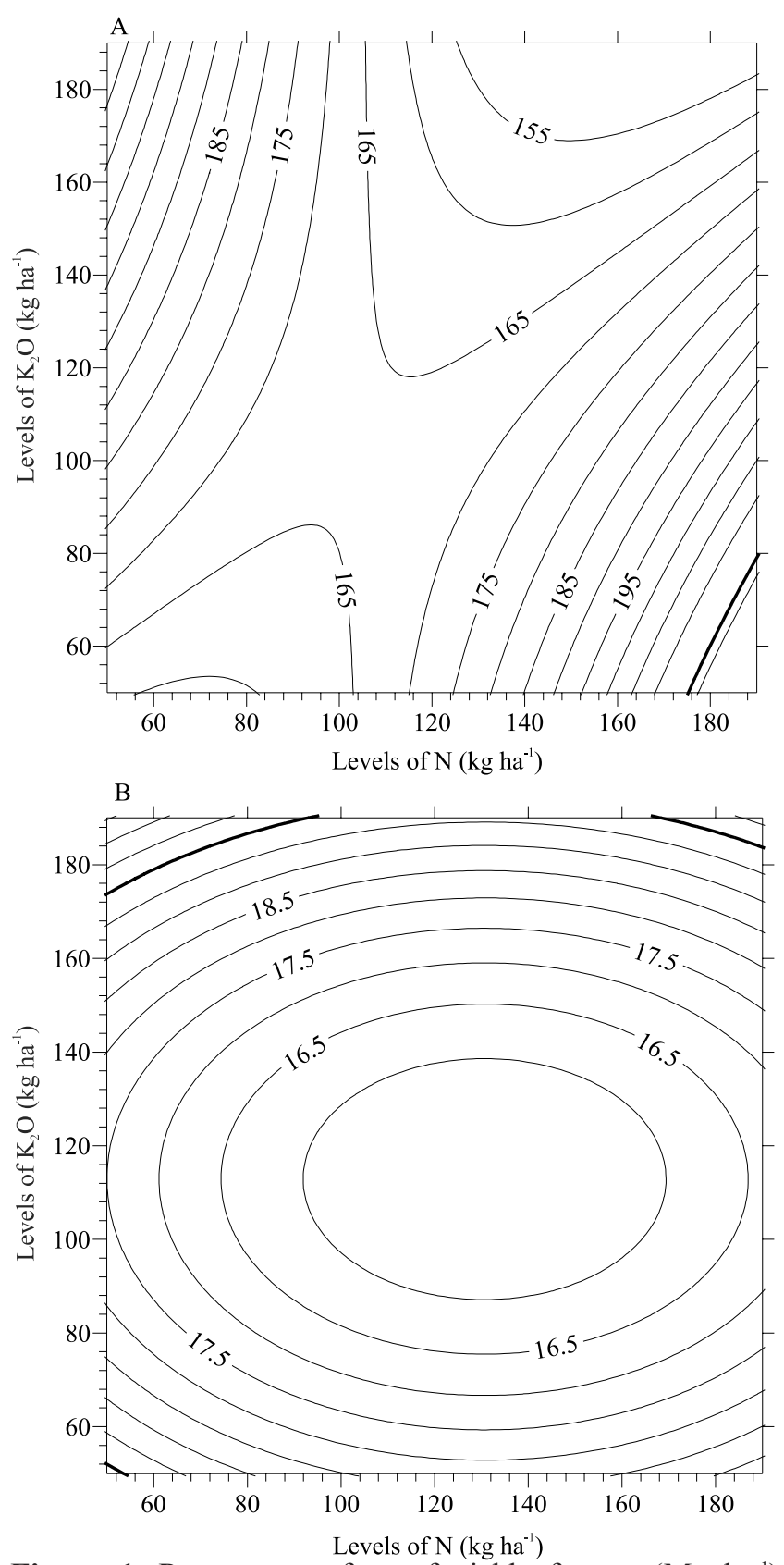

Figure 1. Response surface of yield of stem $\left(\mathrm{Mg} \mathrm{ha}^{-1}\right)$ (A) and Brix of sugarcane broth (B) in the first sugarcane (Saccharum officinarum) crop cycle with application of $\mathrm{N}$ and $\mathrm{K}_{2} \mathrm{O}$ via fertirrigation. 
(Table 2 and Figure 1). However, the response-surface data indicate other combinations of $\mathrm{N}$ and $\mathrm{K}$ that can provide a range of possible stalk yield values, within the limits of the doses of fertilization used up to the highest estimated value of $217.5 \mathrm{Mg} \mathrm{ha}^{-1}$, with the 180 $\mathrm{kg} \mathrm{ha}^{-1} \mathrm{~N}$ and $60 \mathrm{~kg} \mathrm{ha}^{-1} \mathrm{~K}_{2} \mathrm{O}$.

The behavior of the estimated value shows increases of stalk yield, with an increase of $\mathrm{N}$ doses and greater flexibility in the application of $\mathrm{K}_{2} \mathrm{O}$ doses, without affecting the crop biomass productivity. This effect can be explained by the $\mathrm{K}$ content $\left(0.23 \mathrm{cmol}_{\mathrm{c}} \mathrm{dm}^{-3}\right)$ already present in the soil in the experimental site (Table 1), which is above the critical level $\left(2.1 \mathrm{mmol}_{\mathrm{c}}\right.$. $\mathrm{dm}^{-3}$ ) indicated by Raij (1974) and higher than the average soils of the tropical region, where $\mathrm{K}$ levels are usually lower than $0.15 \mathrm{cmol}_{\mathrm{c}} \mathrm{dm}^{-3}\left(1.5 \mathrm{mmol}_{\mathrm{c}} \mathrm{dm}^{-3}\right)$ (Otto et al., 2010).

Theoretically, there is a greater possibility of sugarcane response to the application of fertilizers with $\mathrm{K}$ in soils with an initial concentration of this nutrient classified as low (Raij \& Cantarella 1997; Silva et al., 2007). Andrade Júnior et al. (2012) applied 1,154 mm water depth and optimum levels of $\mathrm{N}\left(114.2 \mathrm{~kg} \mathrm{ha}^{-1}\right)$ and $\mathrm{K}_{2} \mathrm{O}\left(60.1 \mathrm{~kg} \mathrm{ha}^{-1}\right)$, via subsurface drip fertigation, and obtained $207.4 \mathrm{Mg} \mathrm{ha}^{-1}$ maximum stalk yield, at the municipality of União, a microregion of Teresina, in the state of Piauí, Brazil, using the cultivar RB867515 (during the second leaf period). This reinforces the possibility that is possible to achieve a good stalk yield with different combinations of $\mathrm{N}$ and $\mathrm{K}_{2} \mathrm{O}$ doses, as shown in the present study.

Using subsurface drip irrigation (IGS), Dalri \& Cruz (2008) obtained $190.0 \mathrm{Mg} \mathrm{ha}^{-1}$ stalk yield by applying the highest combination of $\mathrm{N}$ and $\mathrm{K}$ established in the study (180 kg ha-1 $\mathrm{N}$ and $180 \mathrm{~kg} \mathrm{ha}^{-1} \mathrm{~K}_{2} \mathrm{O}$ ), evidencing that $\mathrm{N}$ and $\mathrm{K}$ fertigation in sugarcane increase the crop yield. There was no interaction of $\mathrm{N}$ and $\mathrm{K}_{2} \mathrm{O}$ doses for the evaluated parameters of juice/broth technological analyses (Table 2). Although not affected significantly by the interaction of fertilizers, the percentage of soluble solids (Brix) tends to decrease with an increase of $\mathrm{N}$ doses (Figure $1 \mathrm{~B}$ ), as excess $\mathrm{N}$ causes a deleterious effect on the sucrose production, reducing its concentration (Silva et al., 2009).

Salviano et al. (2017) emphasize the export of nutrients in the sugarcane cultivar RB92579, under tropical semiarid conditions, in the order $\mathrm{K}>\mathrm{N}>\mathrm{S}>\mathrm{Ca}>\mathrm{P}>\mathrm{Mg}$, in which $\mathrm{K}$ was the most exported nutrient with $87 \%$ of the total absorbed, corroborating the Brix response surface, for which the highest estimated value was $20.0 \%$ with the following combination: $60 \mathrm{~kg} \mathrm{ha}^{-1} \mathrm{~N}$ and $180 \mathrm{~kg} \mathrm{ha}^{-1} \mathrm{~K}_{2} \mathrm{O}$.

In an experiment with subsurface irrigation using NK $50 \%$, NK100\%, and NK150\% of the standard fertilization equivalent to $120 \mathrm{~kg} \mathrm{ha}^{-1} \mathrm{~N}$ and $120 \mathrm{~kg} \mathrm{ha}^{-1}$ $\mathrm{K}_{2} \mathrm{O}$, via fertigation, Dalri \& Cruz (2008) verified a reduction of the soluble solids content from 18.03 with the NK50\% application to 17.5 with NK100\% application.
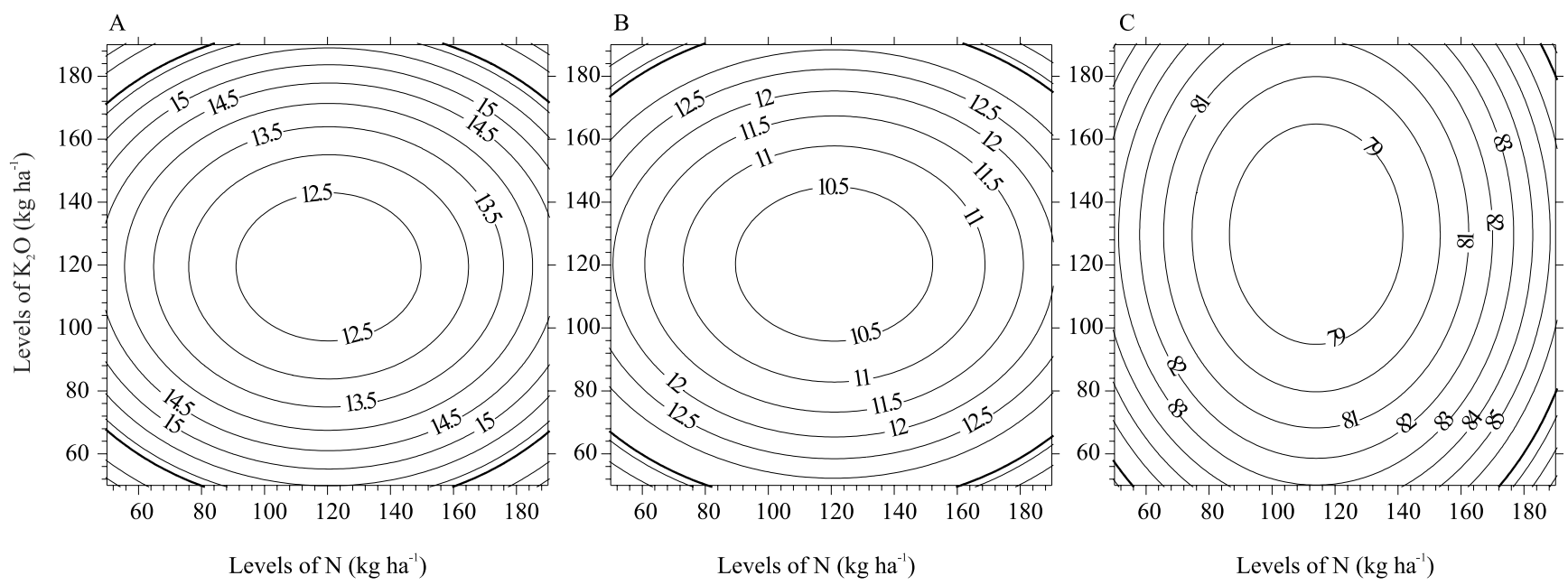

Figure 2. Response surface of the sucrose percentage of the POL-juice(A), POL-cane (B) and purity (C) of the cultivar $\mathrm{RB} 92579$ in the first sugarcane (Saccharum officinarum) crop cycle, with application of $\mathrm{N}$ and $\mathrm{K}_{2} \mathrm{O}$ via fertigation. 
The technological variables POLjuice, POLcane, purity, and fiber did not showed interaction with both applied fertilizers using a subsurface fertigation, which allows us to conclude that the increase of their values from the minimal points possibly occurs within the different combinations of $\mathrm{N}$ and $\mathrm{K}_{2} \mathrm{O}$ for the established levels in the response surface (Table 2 and Figures $2 \mathrm{~A}, \mathrm{~B}$, and C).

These parameters showed the minimum points of $120.3 \mathrm{~kg} \mathrm{ha}^{-1} \mathrm{~N}$ and $119.42 \mathrm{~kg} \mathrm{ha}^{-1} \mathrm{~K}_{2} \mathrm{O} ; 120.9 \mathrm{~kg} \mathrm{ha}^{-1}$ $\mathrm{N}$ and $120.3 \mathrm{~kg} \mathrm{ha}^{-1} \mathrm{~K}_{2} \mathrm{O}$; and $114.0 \mathrm{~kg} \mathrm{ha}^{-1} \mathrm{~N}$ and 129.8 $\mathrm{kg} \mathrm{ha}^{-1} \mathrm{~K}_{2} \mathrm{O}$, with estimated values of: POLjuice $=12.1 \%$, POLcane $=10.1 \%$, and purity $=78 \%$, respectively (Table 2). However, other values can be estimated within the previously established $\mathrm{N}$ and $\mathrm{K}_{2} \mathrm{O}$ levels (Figure $2 \mathrm{~A}$, $\mathrm{B}$, and $\mathrm{C}$ ).

This behavior is interesting, since it allows of a greater flexibility in the application of the best $\mathrm{N}$ and $\mathrm{K}$ dose according to the price of the fertilizers. Oliveira et al. (2012) evaluated the technological characteristics of two sugarcane cultivars under different levels of fertilization and irrigation suppression, and observed an increase of POLjuice with the increment of fertilizers. The highest values were obtained with the highest fertilization $\left(71 \mathrm{~kg} \mathrm{ha}^{-1} \mathrm{~N}\right.$ and $\left.166 \mathrm{~kg} \mathrm{ha}^{-1} \mathrm{~K}_{2} \mathrm{O}\right)$, with $23.1 \%$ for 'RB 855453', and 20.7\% for 'SP80-1816'. The authors verified that the fertilization doses altered the juice/broth quality, according to higher-K amounts of and lower-N amounts.

In the present work, the studied cultivar showed the opposite behavior, as $\mathrm{N}$ affected the increase of POLjuice, POLcane, and purity, with the combination showing the highest-N amount of and lower $\mathrm{K}$ amount. This can be explained by the different responses to $\mathrm{N}$ from some cultivars, which are able to better use the nutrients, as well as the sucrose accumulation, which means that higher doses may not affect broth/juice quality (Rossetto et al., 2002).

Rhein et al. (2016) found that the technological variables Brix, purity, and recoverable total sugar of cultivar SP80-3280, under fertigation conditions, were altered by the application of $\mathrm{N}$ rates via subsurface drip, with significant reductions of the dose of $200 \mathrm{~kg} \mathrm{ha}^{-1} \mathrm{~N}$.

Considering that the production of sugar and alcohol are the result of the stalk productivity, a similarity can be observed between these parameters and stem yield. A significant interaction was observed between $\mathrm{N}$ and $\mathrm{K}$ doses applied to sugarcane in the first cycle of the crop, which indicates the generation of response surfaces in the evaluation of the combined effect of $\mathrm{N}$ and $\mathrm{K}$ in sugar and alcohol productions (Table 2).

The application of treatments, similarly to that of stalk yield, resulted in an estimated value of $16.97 \mathrm{Mg}$
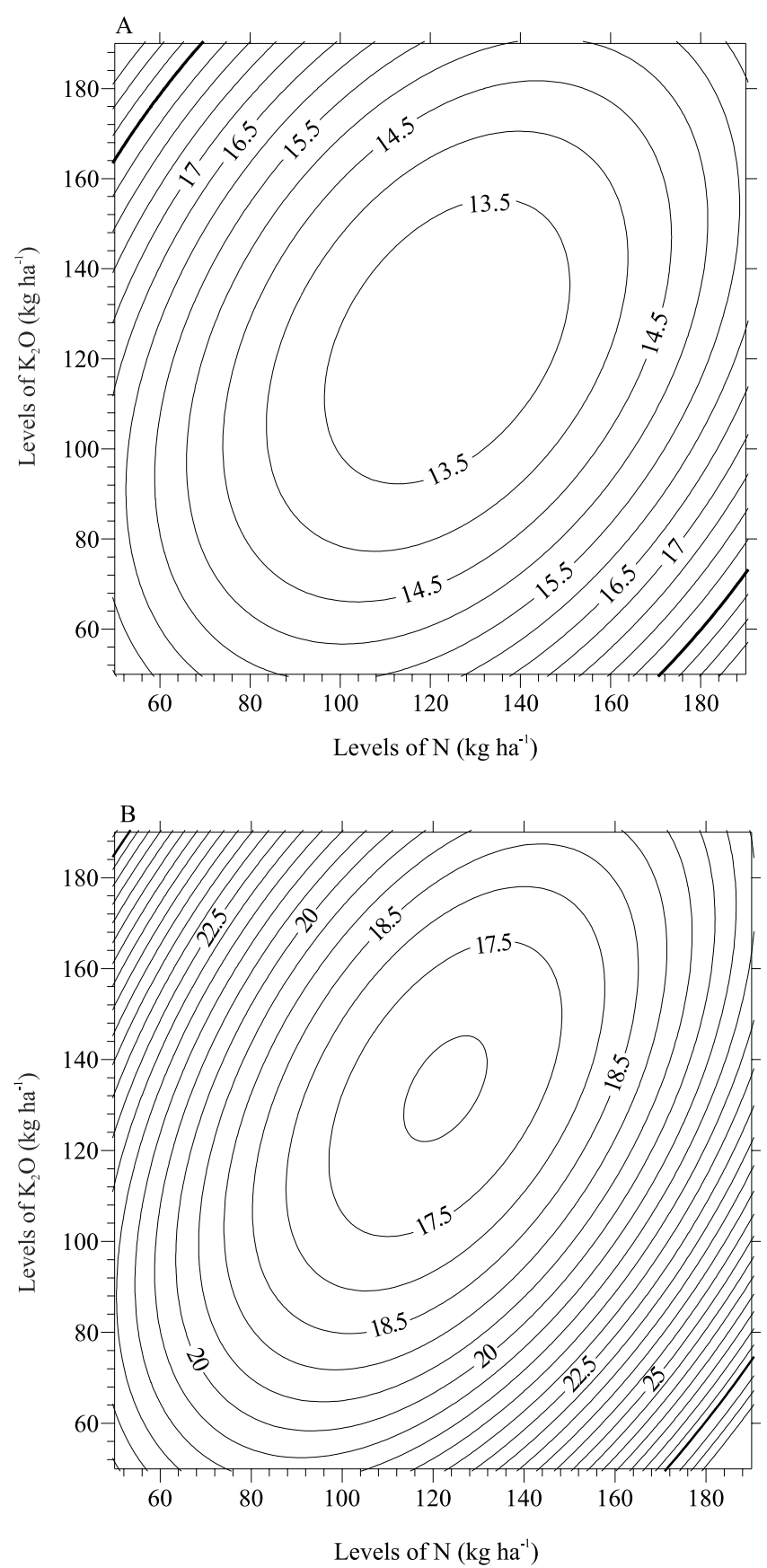

Figure 3. Surface response for alcohol production (A) and total sugar production (B) of the cultivar RB 92579 in the first sugarcane (Saccharum officinarum) crop cycle with application of $\mathrm{N}$ and $\mathrm{K}_{2} \mathrm{O}$ using fertigation. 
ha $^{-1}$ of total sugar production, with the minimum of $122.2 \mathrm{~kg} \mathrm{ha}^{-1} \mathrm{~N}$ and $132.6 \mathrm{~kg} \mathrm{ha}^{-1} \mathrm{~K}_{2} \mathrm{O}$, and $13.07 \mathrm{~m}^{3}$ $\mathrm{ha}^{-1}$ of alcohol production, with the minimum of 123.6 $\mathrm{kg} \mathrm{ha}^{-1} \mathrm{~N}$ and $123.8 \mathrm{~kg} \mathrm{ha}^{-1} \mathrm{~K}_{2} \mathrm{O}$ (Table 2). These values are higher than the maximum values of the average sugar yields $14.2 \mathrm{Mg} \mathrm{ha}^{-1}$ and $10.2 \mathrm{~m}^{3} \mathrm{ha}^{-1}$ alcohol found by Silva et al. (2009) ( $236 \mathrm{~kg} \mathrm{~N}$ plus $222 \mathrm{~kg} \mathrm{~K}_{2} \mathrm{O}$ ), in coverage, and also higher than the values obtained by Dantas Neto et al. (2006) for sugar $12.6 \mathrm{Mg} \mathrm{ha}^{-1}$ and $8.9 \mathrm{~m}^{3} \mathrm{ha}^{-1}$ for alcohol, using $305 \mathrm{~kg} \mathrm{ha}^{-1}$ of the mixture containing $\mathrm{N}$ and $\mathrm{K}$.

The combinations of $\mathrm{N}$ and $\mathrm{K}$ showed that, starting from the minimum doses of $\mathrm{N}$ and $\mathrm{K}_{2} \mathrm{O}$, as $\mathrm{N}$ increases and $\mathrm{K}$ decreases, an increase of total sugar recovery and total alcohol production occurs within a range of values allowed by the limits of the $\mathrm{N}$ and $\mathrm{K}$ doses established with the treatments (Table 2 and Figure 3). It is important to observe that some cultivars exhibit a distinct behavior for $\mathrm{N}$, as they are able to better use the nutrient without affecting broth/juice quality (Rosetto et al., 2002).

The highest estimated yields were $28.8 \mathrm{Mg} \mathrm{ha}^{-1}$ for total sugar production, with the combination of 180 $\mathrm{kg} \mathrm{ha}^{-1} \mathrm{~N}$ and $60 \mathrm{~kg} \mathrm{ha}^{-1} \mathrm{~K}_{2} \mathrm{O}$, and $19.0 \mathrm{~m}^{3} \mathrm{ha}^{-1}$ for alcohol production with $180 \mathrm{~kg} \mathrm{ha}^{-1} \mathrm{~N}$ and $60 \mathrm{~kg} \mathrm{ha}^{-1} \mathrm{~K}_{2} \mathrm{O}$ (Figure $3 \mathrm{~A}$ and $\mathrm{B}$ ). This increase of sugar and alcohol production is more evident from the combination of higher $\mathrm{N}$ doses, mainly above $120 \mathrm{~kg} \mathrm{ha}^{-1}$ up to the highest dose $\left(180 \mathrm{~kg} \mathrm{ha}^{-1}\right)$, and with $\mathrm{K}_{2} \mathrm{O}$ values of 60 $\mathrm{kg} \mathrm{ha}^{-1}$; the same fact was observed for stalk yield. This response with a lower dose of $\mathrm{K}_{2} \mathrm{O}$ may have been favored by the already present potassium content in the soil of the experiment due to the fertilization of the previous cultivation (Table 1). According to Dalri \& Cruz (2008), the residual effect of $\mathrm{N}$ and $\mathrm{K}$ applications to previous crops makes the soil more fertile, and reduces the nutrient demand by the crop.

\section{Conclusions}

1. The highest estimated sugarcane stalk yield of $217.5 \mathrm{Mg} \mathrm{ha}^{-1}$ is achieved with the application of 180 kg ha ${ }^{-1} \mathrm{~N}$ and $60 \mathrm{~kg} \mathrm{ha}^{-1} \mathrm{~K}_{2} \mathrm{O}$.

2. Sugar and alcohol productions increase with fertilization with $\mathrm{N}$ doses above $120 \mathrm{~kg} \mathrm{ha}^{-1}$.

3. The technological variables of sugarcane quality soluble solids, such as apparent sucrose in the juice/ broth, apparent sucrose in sugarcane, purity, and fiber show the best performance with the application of 180 $\mathrm{kg} \mathrm{ha}^{-1} \mathrm{~N}$ and $60 \mathrm{~kg} \mathrm{ha}^{-1} \mathrm{~K}_{2} \mathrm{O}$.

\section{References}

ACOMPANHAMENTO DA SAFRA BRASILEIRA [DE] CANA-DE-AÇÚCAR: safra 2015/16: quarto levantamento, v.2, n.4, abr. 2016.

ANDRADE JÚNIOR, A.S. de.; BASTOS, E.A.; RIBEIRO, V.Q.; DUARTE, J.A.L.; BRAGA, D.L.; NOLETO, D.H. Níveis de água, nitrogênio e potássio por gotejamento subsuperficial em cana-deaçúcar. Pesquisa Agropecuária Brasileira, v.47, p.76-84, 2012. DOI: 10.1590/S0100-204X2012000100011.

ANDRADE JÚNIOR, A.S. de; NOLETO, D.H.; BASTOS, E.A.; MOURA, M.S.B. de; ANJOS, J.C.R. dos. Demanda hídrica da cana-de-açúcar, por balanço de energia, na microrregião de Teresina, Piauí. Agrometeoros, v.25, p.217-226, 2017.

BASTOS, E.A.; ANDRADE JUNIOR, A.S. de. Boletim agrometeorológico de 2013 para o município de Teresina, Piauí. Teresina: Embrapa Meio-Norte, 2014. 38p. (Embrapa Meio-Norte. Documentos, 228).

CALDAS, C. Manual de análises selecionadas para indústrias sucroalcooleiras. Maceió: Sindicato da Indústria do Açúcar e do Álcool do Estado de Alagoas, 1998. 424p.

CARVALHO, C.M. de; AZEVEDO, H.M. de; DANTAS NETO, J.; FARIAS, C.H. de A.; SILVA, C.T.S. da; GOMES FILHO, R.R. Rendimento de açúcar e álcool da cana-de-açúcar submetida a diferentes níveis de irrigação. Revista Brasileira de Ciências Agrárias, v.4, p.72-74, 2009. DOI: 10.5039/agraria.v4ila12.

CARVALHO, C.M. de; AZEVEDO, H.M. de; DANTAS NETO, J.; MELO, E.P. de; SILVA, C.T.S. da; GOMES FILHO, R.R. Resposta dos parâmetros tecnológicos da terceira folha de canade-açúcar submetida a diferentes níveis de irrigação. Revista Brasileira de Ciências Agrárias, v.3, p.337-342, 2008. DOI: 10.5039/agraria.v3i4a113.

CONSECANA. Conselho dos Produtores de Cana-de-açúcar, Açúcar e Álcool do Estado de Pernambuco. Manual de Instruções. $5^{\mathrm{a}}$ ed. Piracicaba, 2006. 112p.

CORREIA, C.B.G.; AZEVEDO, H.M. de; DANTAS NETO, J.; CARVALHO, C.M. de; SILVA, L.L.; FEITOSA, S. de O. Canade-açúcar: parâmetros tecnológicos em função de diferentes lâminas de irrigação e adubação de cobertura. Revista Brasileira de Agricultura Irrigada, v.8, p.26-37, 2014. DOI: 10.7127/rbai. v8n100204.

DALRI, A.B.; CRUZ, R.L.; GARCIA, C.J.B.; DUENHAS, L.H. Irrigação por gotejamento subsuperficial na produção e qualidade da cana-de-açúcar. Irriga, v.13, p.1-11, 2008. DOI: 10.15809/ irriga.2008v13n1p1-11.

DALRI, A.B.; CRUZ, R.L. Produtividade da cana-de-açúcar fertirrigada com $\mathrm{N}$ e $\mathrm{K}$ via gotejamento subsuperficial. Engenharia Agrícola, v.28, p.516-524, 2008. DOI: 10.1590/ S0100-69162008000300012.

Pesq. agropec. bras., Brasília, v.53, n.12, p.1346-1354, Dec. 2018 DOI: 10.1590/S0100-204X2018001200007 
DANTAS NETO, J.; FIGUEREDO, J.L. da C.; FARIAS, C.H. de A.; AZEVEDO, H.M. de; AZEVEDO, C.A.V. de. Resposta da cana-de-açúcar, primeira soca, a níveis de irrigação e adubação de cobertura. Revista Brasileira de Engenharia Agrícola e Ambiental, v.10, p.283-288, 2006. DOI: 10.1590/S141543662006000200006.

DAROS, E.; OLIVEIRA, R.A. de; ZAMBON, J.L.C.; BESPALHOK FILHO, J.C. (Ed.). Catálogo nacional de variedades "RB" de cana-de-açúcar. Curitiba: RIDESA BRASIL, 2010. 136p.

DOORENBOS, J.; KASSAM, A.H. Yield response to water. Rome: FAO, 1979. 193p. (FAO. Irrigation and Drainage Paper, 33).

FARIAS, C.H. de A.; FERNANDES, P.D.; GHEYI, H.R.; DANTAS NETO, J. Qualidade industrial de cana-de-açúcar sob irrigação e adubação com zinco, em Tabuleiro Costeiro paraibano. Revista Brasileira de Engenharia Agrícola e Ambiental, v.13, p. 419-428, 2009. DOI: 10.1590/S1415-43662009000400008.

MAY, A.; SANTOS, F.C. dos; SANTOS, M. de S. dos; SILVA, M.A. da; BERETTA, V.Z. Efeito de doses de nitrogênio sobre a produtividade de cana-de-açúcar em sucessão ao sorgo biomassa. Sete Lagoas: Embrapa Milho e Sorgo, 2016. 17p. (Embrapa Milho e Sorgo. Boletim de pesquisa e desenvolvimento, 141).

MELO, F.B.; ANDRADE JÚNIOR, A.S.; PESSOA, B.L.O. Levantamento, zoneamento e mapeamento pedológico detalhado da área experimental da Embrapa Meio-Norte em Teresina, PI. Teresina: Embrapa Meio-Norte, 2014. 47p. (Embrapa Meio-Norte. Documentos, 231).

OLIVEIRA, F.M. de; ASPIAZÚS, I.; KONDO, M.K.; DIAS BORGES, I. Avaliação tecnológica de variedades de cana-deaçúcar influenciadas por diferentes adubações e supressões de irrigação. Revista Ceres, v.59, p.832-840, 2012. DOI: 10.1590/ S0034-737X2012000600014.

OTTO, R.; VITTI, G.C.; LUZ, P.H. de C. Manejo da adubação potássica na cultura da cana-de-açúcar. Revista Brasileira de Ciência do Solo, v.34, p.1137-1145, 2010. DOI: 10.1590/S010006832010000400013.

PIMENTEL GOMES, F. Curso de estatística experimental. 15.ed. Piracicaba: Esalq, 2009. 451p.

RAIJ, B. van. Calibração de potássio trocável em solos para feijão, algodão e cana-de-açúcar. Ciência e Cultura, v.26, p.575579, 1974.

RAIJ, B.V.; CANTARELLA, H. Outras culturas industriais. In: RAIJ, B. Van; CANTARELLA, H.; QUAGGIO, J.A.; FURLANI, A.M.C. (Ed.). Recomendações de adubação e calagem para o Estado de São Paulo. 2.ed. rev. e atual. Campinas: IAC, 1997. p.233-244. (IAC. Boletim Tecnico, 100).

RHEIN, A.F. de L.; SILVA, M. de A. Nitrogen doses on physiological attributes and yield of sugarcane grown under subsurface drip fertigation. Journal of Plant Nutrition, v.40, p.227-238, 2017. DOI: 10.1080/01904167.2016.1237646.

RHEIN, A.F.L.; PINCELLI, R.P.; ARANTES, M.T.; DELlABIGLIA, W.J.; KÖLlN, O.T.; SILVA, M. de A. Technological quality and yield of sugarcane grown under nitrogen doses via subsurface drip fertigation. Revista Brasileira de Engenharia Agrícola e Ambiental, v.20, p.209-214, 2016. DOI: 10.1590/1807-1929/agriambi.v20n3p209-214.

ROSSETTO, R.; FARHAT, M.; FURLAN, R.; GIL, M.A.; SILVA, S.F. Eficiência agronômica do fosfato natural na cultura da canade-açúcar. In: CONGRESSO NACIONAL DA SOCIEDADE DOS TÉCNICOS AÇUCAREIROS E ALCOOLEIROS DO BRASIL, 8., 2002, Recife. Anais. Recife: STAB, 2002. p.276-282.

SALVIANO, A.M.; MOURA, M.S.B. de; SILVA, T.G.F. da; CARMO, J.F.A. do; BRANDÃO, E.O. Acúmulo e exportação de macronutrientes pela cana de açúcar irrigada no Semiárido brasileiro. Revista Científica Intelletto, v.2, 2017 p.16-27.

SILVA, A.B. da; DANTAS NETO, J.; FARIAS, C.H. de A.; AZEVEDO, C.A.V. de; AZEVEDO, H.M. de. Rendimento e qualidade da cana-de-açúcar irrigada sob adubações de nitrogênio e potássio em cobertura. Revista Caatinga, v.22, p.236-241, 2009.

SILVA, F.C.; MURAOKA, T.; CASTRO, P.R. de C. e. Avaliação da adubação com nitrogênio e potássio em soqueiras de cana-de-açúcar sem queima. Campinas: Embrapa Informática Agropecuária, 2007. (Embrapa Informática Agropecuária. Boletim de pesquisa e desenvolvimento, 16).

SILVA, M. de A.; ARANTES, M.T.; RHEIN, A.F de L.; GAVA, G.J.C.; KOLLN, O.T. Potencial produtivo da cana-de-açúcar sob irrigação por gotejamento em função das variedades e ciclo. Revista Brasileira de Engenharia Agrícola e Ambiental, v.18, p.241-249, 2014. DOI: 10.1590/S1415-43662014000300001.

SOUZA, J.K.C. de; SILVA, S.; DANTAS NETO, J.; SILVA, M.B.R.; TEODORO, I. Importância da irrigação para a produção de cana-de-açúcar no Nordeste do Brasil. Revista Educação Agrícola Superior, v.27, p.133-140, 2012. DOI: 10.12722/0101756X.v27n02a10.

TEIXEIRA, E.B.; BOLONHEZI, A.C.; FERNANDES, F.M.; RIBEIRO, N.A.; QUEIROZ, C.J. Características tecnológicas do caldo de variedades de cana-de-açúcar cultivadas em solo de cerrado com diferentes níveis de adubação fosfatada. Científica, v.44, p.23-34, 2016.

TEIXEIRA FILHO, M.C.M.; BUZETTIL, S.; GARCIA, C.M. de P.; BENETT, C.G.S.; RODRIGUES, M.A. de C.; MAESTRELO, P.R.; CELESTRINO, T. de S.; GAZOLA, R. de N. Qualidade tecnológica e produtividade agroindustrial de cana-de-açúcar submetida a adubação com zinco. Semina: Ciências Agrárias, v.34, p.1603-1614, 2013. DOI: 10.5433/1679-0359.2013v34n 4 p1603.

THORNTHWAITE, C.W.; MATHER, J.R. The water balance. Centerton: Drexel Institute of Technology, Laboratory of Climatology, 1955. 104p. (Publications in Climatology, v.8).

Received on April 28, 2017 and accepted on March 6, 2018

Pesq. agropec. bras., Brasília, v.53, n.12, p.1346-1354, Dec. 2018 DOI: 10.1590/S0100-204X2018001200007 